LWT

May 2018, Volume 91, Pages 431-438

http://dx.doi.org/10.1016/i.lwt.2018.01.047

http://archimer.ifremer.fr/doc/00423/53475/

(c) 2018 Elsevier Ltd. All rights reserved.

\title{
Effect of salting and cold-smoking procedures on Atlantic salmon originating from pre-or post rigor filleted raw material. Based on the measurement of physiochemical characteristics
}

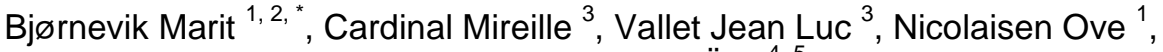 \\ Arnarson Gudmundur Örn ${ }^{4,5}$
}

\footnotetext{
${ }^{1}$ Nord University, 8029, Bodø, Norway

2 Institute of Marine Research, Matre Aquaculture Research Station, Norway

3 IFREMER, Laboratorie Génie Alimentaira Valorisation des Produits rue de l'ile d' Yeu, BP 21105, 44311, Nantes Cedex 3, France

${ }_{5}^{4}$ Matís, Icelandic Food and Biotech R\&D, Vínlandsleið 12, 113, Reykjavík, Iceland

${ }^{5}$ Matra, Technological Institute of Iceland, Iceland

* Corresponding author : Marit Bjørnevik, email address : $\underline{\text { marit.bjornevik@nord.no }}$
}

\begin{abstract}
:
Different methods in use for cold smoking of salmon affect product yield and quality. The combinations of filleting time (pre or post), salting methods (dry or injection), salting targets (2.5 or $4 \%$ ) and smoking temperatures $\left(15\right.$ or $25^{\circ} \mathrm{C}$ ) were studied during 6 weeks of $4{ }^{\circ} \mathrm{C}$ cold storage. Salting method had the greatest influence on flesh quality. Injection salting led to $15 \%$ higher fillet yield, moderate to strong gaping score, softer texture, and paler fish compared with dry salting. Pre-rigor filleting reduced fillet gaping from a moderate to minor score, but only in dry salted fillets. Smoking at $15^{\circ} \mathrm{C}$ reduced yield by $0.5 \%$ in injected salted fish, compared with $25^{\circ} \mathrm{C}$. The combination of pre-rigor filleting, dry salting and $15^{\circ} \mathrm{C}$ smoking temperature gave the lowest gaping incidence and highest shear force and flesh colour. Liquid loss increased by $240 \%$ and the L-value by 6.5 units during 6 weeks cold storage, whereas the other quality parameters measured showed only small changes during the storage period.
\end{abstract}

\section{Highlights}

Salting technique is more important for flesh quality than filleting time, salt target and smoking temperature. The combination of pre-rigor filleting, dry salting and $15^{\circ} \mathrm{C}$ smoking temperature gave lower gaping, higher shear force and colour. I Injection salting increased fillet yield. L Liquid loss increased during cold storage.

Keywords : Salmo salar, Flesh quality, Texture, Liquid loss, Fillet yield, Cold storage 


\section{Introduction}

In 2016, Norway produced 1233000 metric tons of farmed Atlantic salmon (Salmo salar

39 L.) (Statistics_Norway, 2017). A substantial part of this is exported to other European

40 countries, where it is processed as cold smoked salmon for the European market. Large

41 quantities of Norwegian salmon is exported as whole gutted fresh fish on ice, arriving 3 to 5

42 days post mortem at a processing company for further filleting and processing to produce cold

43 smoked products. Modern slaughter technology reduces pre-slaughter stress allowing

44 industrial pre rigor filleting. Pre rigor filleting has positive effects, increasing the freshness of

45 fish at market, reducing total weight of fish handled to exported fillets only. Pre rigor filleting

46 increases fillet thickness, reduces the incidence and severity of gaping and increases colour 
score in raw Atlantic salmon compared with filleting post rigor (Skjervold et al., 2001b, Taylor et al., 2002).

The smoking process includes several steps, and for each the choice of control parameters such as salting method, concentration of brine, or smoking temperature determines specific finished product characteristics (Cardinal et al., 2001, Birkeland et al., 2003, Birkeland and Bjerkeng, 2005, Birkeland et al., 2007). Processing salmon fillets while still in pre or in-rigor state is possible, but studies have shown that salt uptake is reduced compared with post rigor fillets (Wang et al., 1998, Rørå et al., 2004). No work has addressed the effect of pre rigor filleting on the uptake of salt and smoke when processed post rigor, compared with post rigor filleting. The change in fillet shape might affect the microstructure and thereby the absorption rate of salt and smoke within the muscle, as well as gaping and colour of the final product.

Different salting methods are reported to affect the yield, fillet colour, texture and gaping in salmon (Sigurgisladottir et al., 2000, Cardinal et al., 2001, Birkeland et al., 2003, Birkeland et al., 2004a, Martinez et al., 2012). Cold smoked salmon on the European market typically contain between $1.7 \%$ to $5.1 \%$ salt in the water phase (Cardinal et al., 2004). The uptake and distribution of salt in the fillet depends on the method used, brine concentration and brining time (Sigurgisladottir et al., 2000, Rørå et al., 2004, Birkeland et al., 2007). Salt can be added by dry salting, brine salting or injection salting. Traditionally the two first methods are commonly used by the salmon processing industry (Espe et al., 2001, Mørkøre et al., 2001). However injection salting is a rapid curing method which results in a significantly higher yield after both salting and smoking (Birkeland et al., 2003, Birkeland et al., 2007). This contrasts with dry salting where water leaks out of the fish, resulting in a lower yield after salting and smoking (Cardinal et al., 2001). The type of salting method chosen will therefore have an economic impact. 
Most of the available literature on smoked salmon refers to smoking temperatures between

20 and $30^{\circ} \mathrm{C}$ (Sigurgisladottir et al., 2000, Cardinal et al., 2001, Espe et al., 2001, Birkeland et al., 2004b, Hultmann et al., 2004, Rørå et al., 2004, Løje et al., 2007, Varlet et al., 2007). Smoke contains several phenolic compounds imparting taste to the product, the absorption of which is dependent on smoking temperature and smoking time (Cardinal et al., 2001, Sérot et al., 2004). Texture and liquid loss of Atlantic salmon changes with smoking temperatures between 20 and $30^{\circ} \mathrm{C}$, higher temperatures increasing both texture as well as liquid loss (Cardinal et al., 2001, Hultmann et al., 2004). Although there is smoked salmon on the market processed below $20^{\circ} \mathrm{C}$, literature about the effect of such low temperatures on absorption of smoke components and flesh quality is sparse.

Although there are many published studies on cold smoked salmon, few deal with the combined effects of different processing procedures. There is no published literature on differences in salt and phenolics uptake in pre and post rigor filleted salmon, when both are salted post rigor, or the effect of smoking temperatures below $20^{\circ} \mathrm{C}$. There are also few studies dealing with the stability of liquid loss, colour and texture in smoked salmon during cold storage for more than 2 weeks. Therefore, this study aimed to examine the effects of time of filleting (pre or post rigor) and different aspects of the smoking process on smoked salmon quality. We assessed the combined effects of dry versus injection salting, 2.5 versus $4.0 \%$ salt concentration, and $15^{\circ} \mathrm{C}$ versus $25^{\circ} \mathrm{C}$ smoking temperature on yield, texture, fillet gaping, colour, chemical content and microstructure, during both the manufacturing process and cold storage for up to 6 weeks. 


\section{Materials and methods}

97

98

99

100

101

102

103

104

105

106

107

108

109

110

111

112

113

114

115

116

\subsection{Raw materials}

Farmed superior Atlantic salmon (Salmo salar, weight $4267 \pm 247 \mathrm{~g}, \mathrm{n}=208$ ) were slaughtered locally at Marine Harvest, Sotra, Norway. The fish had been fed commercial feed from Skretting (Atlantic XE 2000 and Orion XE 12mm, both containing $50 \mathrm{mg}$ astaxanthin and $40 \%$ lipid), during the last 6 months before slaughter. All fish were dispatched on the same day using the slaughterhouse commercial procedure for slaughtering, bled in chilled seawater, gutted and washed. One half of the group (104 fish) was immediately filleted and trimmed manually at Institute of Marine Research (IMR), Matre, Norway. Before onset of rigor mortis (pre rigor), fillets from both sides were individually marked, packed in plastic and covered with ice. The remaining 104 fish were gutted, packed on ice, and shipped to IFREMER (French Research Institute for the Exploration of the Seas), Nantes, France. Here they were kept for 5 days post harvest, to ensure fish were out of rigor mortis (post rigor), before being filleted and trimmed manually and both fillets individually marked. All salting and smoking procedures took place at IFREMER.

\subsection{Processing}

\section{Salting methods}

Two salting methods (dry or injection; DS or IS), two salt targets $(2.5 \%$ or $4.0 \%$ in smoked fish muscle; $\mathrm{S} 2.5 \%$ and $\mathrm{S} 4.0 \%)$ and two smoking temperatures $\left(15^{\circ} \mathrm{C}\right.$ or $25^{\circ} \mathrm{C} ; \mathrm{T}^{\circ} 5^{\circ} \mathrm{C}$ and $\mathrm{T} 25^{\circ} \mathrm{C}$ ) were trialled, resulting in 16 different treatment groups with 22 fillets per group. The two fillets from the same fish were processed using the same salting procedure, and thereafter right and left fillet were smoked randomly at either $15^{\circ} \mathrm{C}$ or $25^{\circ} \mathrm{C}$. A total of 32 fish, 16 pre rigor and 16 post rigor, were left unprocessed and used for raw material analyses (Figure 1). 
120 For dry salting fillets were placed on grids and covered with rock salt (Salinor) with E535 and

121 ferronitrite $(20 \mathrm{mg} / \mathrm{kg})$. Fillets were dry salted for 5 hours to achieve $2.5 \%$ salt concentration

122 in the smoked salmon muscle, and for 12 hours to achieve $4.0 \%$ salt concentration.

123 Afterwards the fillets were rinsed briefly with water $\left(15^{\circ} \mathrm{C}\right)$. Brine-injection, $160 \mathrm{~g} \mathrm{~L}{ }^{-1}$ or 300

$124 \mathrm{~g} \mathrm{~L}^{-1}$ (to achieve $2.5 \%$ or $4 \%$ salt concentration in smoked salmon muscle respectively) was 125 carried out with a Injecstar B 152/72 injector modified for fish (equipped with 72 needles, 2

$126 \mathrm{~mm}$ in diameter). Injection pressure was $<2$ bar, and all fish were injected for 60 seconds.

128

129

130

131 storage time.

\section{Cold smoking}

Smoking was carried out in a closed air-conditioned cabinet equipped with an autocombustion independent generator using beech sawdust with $20 \%(\mathrm{w} / \mathrm{w})$ water added to the wood, air speed $2 \mathrm{~m} / \mathrm{s}$. Fillets were randomly distributed on the cabinet's grids and smoked at $15^{\circ} \mathrm{C}$ for $4 \mathrm{~h}$, or at $25^{\circ} \mathrm{C}$ for $2 \mathrm{~h}$. Brine-injected fillets were dried before smoking to control the final water content of the product: 3 hours at $15^{\circ} \mathrm{C}$ for the $15^{\circ} \mathrm{C}$ samples and 2 hours at $22^{\circ} \mathrm{C}$ for the $25^{\circ} \mathrm{C}$ samples.

\section{Slicing and storage}

All fillets were stored at $4^{\circ} \mathrm{C}$ overnight before one fillet from each fish was sliced and vacuum packed, three slices per packet, 4-5 packets per fillet. The other fillet was kept whole. Both vacuum-packed slices and whole fillets were cold stored at $4^{\circ} \mathrm{C}$ for $1,2,4$ or 6 weeks before further analysis (Attachment 1). Five or six fish per group was analysed for each 


\subsection{Analysis}
Each fillet was weighed and analysed for gaping and colour before and after processing. From the raw unprocessed fillets (64 fillets) and from the whole processed fillets (176 fillets), the entire section under the dorsal fin was sent to Technological Institute of Iceland, Iceland (IceTec), for analysis of texture shear force and microstructure. IMR received the remainder of each fillet for analyses of astaxanthin, water and fat.

Shear force was analysed in raw and processed fillets immediately on arrival at IceTec (4 days after smoking), and after 1, 2, 4 and 6 weeks of cold storage. Microstructure was analysed in injection salted fillets only, 32 raw and 32 processed fillets. Vacuum-packed slices with processed salmon were analysed for salt and phenol content after 1 week, $\mathrm{pH}$ after 2 weeks, and colour and liquid loss after 1, 2, 4 and 6 weeks of cold storage. Fat, water and astaxanthin content were analysed in raw fillets immediately after arriving IMR, and in vacuum packed slices of processed fish after 1 and 4 weeks of cold storage (Attachment 1).

\subsubsection{Fillet yield}

Fillet yield is a measure of the change in fillet weight during salting and smoking. Total fillet weight was measured on raw fillets (5 days post mortem) and after processing. Fillet yield was calculated according to the formula:

Fillet yield \%: $=($ Wprocessed $-\mathrm{Wraw}) \times \mathrm{Wraw}^{-1} \mathrm{x} 100 \%$

Where Wraw = weight $(\mathrm{g})$ of raw fillet and Wprocessed= weight $(\mathrm{g})$ of processed fillets.

\subsubsection{Gaping score}

Gaping score was assessed visually on whole fillets, along the head-tail axis and was independent of fillet length. A scale from 1 to 4 was used; where 1 is no gaping, 2 minor gaping (gaping covering 1-5 cm longitudinally of the fillet), 3 moderate gaping $(6-10 \mathrm{~cm})$ and 4 strong gaping $(>10 \mathrm{~cm})$. Fillets were not subjected to removal of pin bones. 
170

171

172

173

174

175

176

177

178

179

180

181

182

183

184

185

186

187

188

189

190

191

192

\subsubsection{Flesh colour}

Flesh colour was measured at six locations evenly spread over the whole raw and newly smoked fillet. During cold storage, colour was measured at three locations in each of three vacuum packages per treatment group and storage time. The colour was quantified using a portable Hunterlab Miniscan/EX instrument $\left(10^{\circ}\right.$ standard observer, illuminant D65, Hunter Associates Laboratory Inc, 11491 Sunset Hills Road, Reston, Virginia, USA) calibrated to a white and a black standard. The $L^{*}$ variable represents lightness $\left(L^{*}=0\right.$ for black, 100 for white), the $a^{*}$ scale represents the intensity of red and the $b^{*}$ scale the intensity of yellow.

\subsubsection{Shear force}

Shear force was assessed using a Texture Analyser (TA-XT2 Texture Analyser; Stable Micro system, Haslemere, Surrey, UK), equipped with a V-shaped blade with a thickness of $3.2 \mathrm{~mm}$, height $125 \mathrm{~mm}$ and width $70 \mathrm{~mm}$. The blade cut into fillet samples at a speed of 3 $\mathrm{mm} / \mathrm{s}$. The maximum peak force $(\mathrm{N})$ required to shear through the sample was recorded as shear force, and was regarded as the toughness of the fillet.

\subsubsection{Microstructure}

Samples for microstructure analysis were collected from the white muscle below the dorsal fin. Preparation of samples, cryo-sectioning, staining and image viewing was as described by Sigurgisladottir et al. (2001). Samples were taken from the fillets using a cork knife and frozen in liquid nitrogen. Specimens were sectioned frozen at $-27^{\circ} \mathrm{C}$ in a cryostat (Leica CM1800, Heidelberg, Germany) for transverse cuts, $10 \mu \mathrm{m}$ thick, and stained with Orange G and then methyl blue. The samples were examined under a microscope (Leica DMRA2) at 
193 100x and 200x magnification. A minimum of 300 cross sections of white muscle fibre were

194 measured from each fish.

195

196

197

198

199

\subsubsection{Chemical analysis}

Duplicates of $1 \mathrm{~g}( \pm 0.0001 \mathrm{~g})$ fish muscle homogenate were weighed into extraction tubes for analysis of astaxanthin, and 1.5-2 grams of anhydrous $\mathrm{Na}_{2} \mathrm{SO}_{4}$ added and adjusted to 10 $\mathrm{ml}$ with acetone. Astaxanthin was separated from other carotenoids on an HPLC system (Hewlett Packard Series 1100, Hewlett Packard Company, Germany) using acetonitrile/ dichlormethane/methanol/water/propionic acid (68:22:4:3:3, v/v/v/v/v) as the mobile phase, flow rate was $1.0 \mathrm{ml} \mathrm{min}^{-1}$, temperature $1^{\circ} \mathrm{C}$, and absorption of astaxanthin determined at 476 nm. The concentration of astaxanthin was determined using external standards. Crystalline astaxanthin (Hoffmann-La Roche, Basle, Switzerland), was dissolved in an acetone/chloroform mixture $(85: 15)$ to produce a stock solution containing $120 \mu \mathrm{g} \mathrm{ml}{ }^{-1}$ astaxanthin, and further diluted with acetone to provide working standards. The astaxanthin content of the standard solutions was determined with a spectrophotometer at $476 \mathrm{~nm}$, assuming an extinction coefficient of 2100.

The other chemical analyses were performed in triplicate. Dry matter content was analysed by oven drying of $3 \mathrm{~g}$ salmon at $105^{\circ} \mathrm{C}$ until a constant weight was reached, while total fat was determined gravimetrically after extraction with ethyl acetate. Total phenol was quantified by the method described in the French standard for smoked salmon (NF V 45-065, 1995). Salt content was measured with a Chloride Analyser 926 (Corning, Halstead UK).

\subsubsection{Liquid loss}

Slices of $16 \mathrm{~g}( \pm 0.0001 \mathrm{~g})$ processed salmon were placed on pre-weighed absorbent pads $(13 \times 9 \mathrm{~cm})$, made of perforated plastic and filled with absorbent material (Cryovac Norway, 
A/S, Oslo, Norway). The fish and pad were covered with aluminium foil, left at $20^{\circ} \mathrm{C}$ for 20 hours, the aluminium foil and fish removed, and the pad weighed for calculation of liquid loss (Mørkøre et al., 2002). Liquid loss \% = Increase in pad weight x (fish weight $)^{-1} \mathrm{x} 100$. $^{-}$

\subsection{Statistical analyses}

Analysis of variance was carried out using the General Linear Model (GLM) module of the IBM SPSS Statistics software package (Version 20, 2011) The time of filleting (pre or post rigor), salting method (dry or injection salting), salt target (2.5 or 4\%) and smoking temperature $\left(15\right.$ or $\left.25^{\circ} \mathrm{C}\right)$ were entered as treatment factors into full factorial models. Separate univariate analyses were performed for each response variable. Storage time $(1,2,4$, and 6 weeks) was used as a covariate in the model when analysing parameters measured during storage. Only significant interactions are reported. Data presented in figures and tables, except for fillet yield, are mean values based on those effects with highest significance in the

GLM. Fillet yield was analysed using the non-parametric Mann Whitney U-test. Other data analysed using one-way anova, followed by a Student-Newman_Keul post hoc test. Correlation between selected parameters was analysed using a Pearson correlation test. Treatment group averages are reported as mean \pm standard deviation in tables, figures and text. A significance level of $\mathrm{p}<0.05$ was chosen.

\section{Results}

The raw fillet mean weight was $1408 \pm 91 \mathrm{~g}$, and the mean values of astaxanthin, fat and water in the raw fillets $5.33 \pm 0.79 \mathrm{mg} \mathrm{kg}^{-1}, 15.8 \pm 1.8 \mathrm{~g} \mathrm{~kg}^{-1}$ and $64.2 \pm 1.6 \mathrm{~g} \mathrm{~kg}^{-1}$ respectively.

240 The mean colour of raw fillets were $55 \pm 1,26 \pm 1$ and $23 \pm 1$ for $\mathrm{L}^{*}-\mathrm{a}^{*_{-}}$and $\mathrm{b}^{*}$-values

241 respectively. The salt target chosen (S2.5\% and S4.0 \%), was only achieved for IS fish, 
242 whereas DS had $25 \%$ and 40\% lower salt content than the respective levels of IS fish (Tab.2).

243 Mean $\mathrm{pH}$ values were $6.1 \pm 0.1$ after processing and $6.3 \pm 0.1$ after 2 weeks of storage.

244 Treatment effects analysed with anova and their interactions on processed fish are shown 245 in table 1.

\subsection{Fillet yield}

Salting method had a strong influence on the fillet yield in smoked fish (Fig.2). Fillet yield was $92.7 \pm 0.7 \%$ in DS groups, equivalent to a $7 \%$ weight reduction compared with raw fillets. The yield for IS fillets was $106.7 \pm 1.8 \%$, or a $6-7 \%$ weight increase compared with raw fillets. In total, the weight differences between IS and DS fillets after smoking was 14-15\% (Fig 2) (Independent Mann-Whitney U-test, $\mathrm{p}<0.001$ ). There was a significant effect of salting target and smoking temperature on fillet yield, but this was small. S2.5\% gave $1 \%$ higher fillet yield than $\mathrm{S} 4.0 \%$, and IS-T25 ${ }^{\circ} \mathrm{C}$ fillets had $0.5 \%$ higher fillet yield than IS-T15 ${ }^{\circ} \mathrm{C}$ (effect of temperature on yield in dry salted fish $=\mathrm{NS}$ ).

\subsection{Gaping and microstructure}

Gaping score was significantly affected by filleting time and salting method (Fig.3A). IS rigor filleted fish (Fig. 3B).

\subsection{Shear force, liquid loss, $L$ - and $a^{*}$-value)}

265 Shear force, liquid loss, L-value and $\mathrm{a}^{*}$-value over 6 weeks of cold storage are shown in 266 Fig.4. Shear force was affected by filleting time, salting method and smoking temperature 
(Tab.1). Post rigor filleting DS-T15 ${ }^{\circ} \mathrm{C}$, was characterised by higher shear force than pre-rigor

filleting IS-T $25^{\circ} \mathrm{C}$. Shear force was not affected by storage, remaining consistent throughout the 6 weeks of cold storage. There was a significant interaction between salting method and salt target, where a slightly higher shear force was apparent at S2.5\% in DS fish, but this was reversed in IS fish. In the IS group, S4.0\% resulted in 1 newton higher shear force compared

272 with S2.5\%. Liquid loss (LL) was affected by salting method and storage (Tab.1). LL 273 increased during storage and was higher in DS than IS after 6 weeks of storage. DS resulted in 274 significantly lower L-value and higher a-value, (Fig.4C, 4D, Tab.1). The L-value was also 275 affected by salt target and smoking temperature. Approximately the L-value was one unit 276 higher at S2.5\% compared with S4.0\% (mean values not shown), and similarly one unit 277 higher at $\mathrm{T} 25^{\circ} \mathrm{C}$ compared with $\mathrm{T} 15^{\circ} \mathrm{C}$.

\subsection{Chemical content}

Filleting time had no significant effect on salt and phenol content, but phenol was affected by salt target and smoking temperature. Phenol content was higher in fillets smoked at $15^{\circ} \mathrm{C}$ compared with $25^{\circ} \mathrm{C}$. At $\mathrm{T} 25^{\circ} \mathrm{C}$ phenol content was affected by salt target, being lower at 283 S4.0\% (Fig.3C).

Table 2 shows the result for astaxanthin, salt, fat and water in processed fillets. Retention of astaxanthin through the smoking process was affected by both salting method and smoking temperature (Tab.1). DS-T15 ${ }^{\circ} \mathrm{C}$ had $1.5 \mathrm{mg} \mathrm{kg}^{-1}$ higher astaxanthin content than $\mathrm{IS}-\mathrm{T} 25^{\circ} \mathrm{C}$ 287 after the first week of storage. DS fillets had $2 \%$ higher fat content than IS fillets in the first 288 week after smoking, but the differences disappeared during 4 weeks of storage. DS fillets also 289 had significantly lower water content than IS. There was a significant effect of increased salt 290 target, resulting in lower water content. 


\subsection{Correlation}

Shear force showed a negative overall significant relationship with gaping $(r=-0.33$, $\mathrm{p}<0.001, \mathrm{n}=46)$ and with the L-value $(\mathrm{r}=-0.44, \mathrm{p}<0.001)$, which means firmer fish has less gaping, and darker flesh. Liquid loss was not related to fat or water content, but was positively related with the L-value.

\section{Discussion}

299

\subsection{Effect of filleting time}

Pre-rigor filleting reduced fillet gaping, which has been observed in raw salmon fillets (Skjervold et al., 2001b). The phenomenon of gaping, the process where a fillet separates into myocomata, renders the flesh unsuitable for production of high value products such as slices of cold-smoked salmon. Fillet gaping, texture, and colour are important issues for the smoked processing industry, and are reason for complaint. Earlier studies have shown that pre-rigor filleting results in firmer texture (Skjervold et al., 2001a). This was not the case in our study, as lower shear force was found in pre-rigor fillets after smoking. When muscles are going through rigor mortis without being attached to the backbone, the myofibres can shorten, with an increase in white muscle fibre area or diameter as a result, as apparent in our study. Skjervold comparing fresh pre and post rigor filleted Atlantic salmon 7 days post mortem found no differences in muscle fibre diameter between groups (Skjervold et al., 2001b).

\subsection{Effect of salting method}

The salting method, dry or injection, was the factor most strongly influencing quality of smoked salmon. IS resulted in $14-15 \%$ higher yield than DS. Yield is a crucial economic issue for smoking companies, and similar differences in product yields have been reported in previous studies (Sigurgisladottir et al., 2000; Cardinal et al., 2001; Torrissen et al., 2001; 
317 Mørkøre et al., 2001; Birkeland et al., 2003; Birkeland et al., 2004). In DS the initial brine

318 film on the fillet surface will transfer water from the fish, dissolving salt crystals near the

319 surface. Water will leak from the fish reducing fillet weight. During IS, water and salt are

320 injected into the fish muscle. With salt concentrations below $1 \mathrm{M}$ brine, as in our study, salt

321 will bind to protein, so the water added will stay inside the muscle dissolving salt crystals and

322 leading to an increase in fillet weight (Barat et al., 2003). This contention is supported by the

323 higher water content of injection-salted fillets, which also led to a lower percentage of fat in

324 this product.

325 Reduced gaping in DS compared with IS has previously been reported (Birkeland et al.,

326 2004a). IS involves needles piercing the flesh, as well as brine being forced into the fillets. It

327 is not unexpected that such treatment may affect the fine connection between muscle fibres

328 and connective tissue, thereby increasing gaping score. A combination of pre rigor filleting

329 and DS resulted in the lowest gaping score in our study, whereas post rigor filleting and IS

330 increased gaping score by 1.5 - 2 units. Higher shear force in DS compared to IS is in 331 agreement with other studies (Birkeland et al., 2004a). The shear force in DS was 25\% higher 332 than in IS.

333 Darker colour score and higher astaxanthin content in DS salmon has been reported 334 previously (Choubert et al., 1992, Cardinal et al., 2001, Birkeland et al., 2004a, Birkeland et 335 al., 2004b, Martinez et al., 2012). Colour is affected by changes in the fillet surface, 336 contingent upon changes in surface structure or water content, making dry salted fish appear 337 darker. A higher astaxanthin content may be due to higher preservation and less pigment 338 oxidation in DS compared with IS. But it can also be a consequence of water loss during dry 339 salting, as argued by Choubert et al. (1992). In contrast Birkeland et al. (2004b) found no 340 influence of salting method (dry or injection) on astaxanthin in Atlantic salmon. 
The leaking of liquid in vacuum-packed smoked salmon is a well-known issue and may

342 lead to downgrading of the product. The higher liquid loss in DS fish after 6 weeks might be 343 related to higher protein denaturation in this group. Increasing salt content has been shown to 344 increase liquid loss in cooked salmon, but at higher salt content levels than in our experiment 345 (Ofstad et al., 1995).

\subsection{Effect of salt target}

The lower salt concentration achieved in the DS groups may have prevented direct comparison of the groups. Salt target had little influence on salmon fillet quality, only affecting fillet yield, water content and L-value.

The lower water content and fillet yield with increasing salt content are in agreement with previous work (Jittinandana et al., 2002, Birkeland and Bjerkeng, 2005, Birkeland et al., 2007, Rizo et al., 2013). Increase in salt content decreases the stable hydrophilic surface and increases protein-protein interaction, leading to water leaking out of the fillet (Arason et al., 2014), explaining the decrease in yield with increasing salt target.

The salt content is comparable with what is normally found in French Manufacture, where 2-3\% $\mathrm{NaCl}$ are reported. Salt together with phenol content and storage temperature are 358 important factors controlling microbiological growth, and thereby both sensory quality and 359 the food safety (Hwang, 2009). Though microbiology data are not available, salt level below 6 $360 \%$ in the water phase are not sufficient to prevent growth of the pathogen bacteria Listeria 361 monocytogensis (Peterson et al., 1993, Truelstrup Hansen et al., 1995). But the higher salt 362 content in the IS group should prevent any microbial growth more than in the DS group 363 (Hwang, 2009). The salting method itself, dry or brine injection, is not found to effect growth 364 of L.monocytogenesis (Niedziela et al., 1998). 


\subsection{Effect of smoking temperature}

The weight gain measured as fillet yield in IS fillets was lower at $\mathrm{T} 15^{\circ} \mathrm{C}$ than at $\mathrm{T} 25^{\circ} \mathrm{C}$.

This is in agreement with Cardinal et al (2001), who reported higher total weight loss after

smoking at $20^{\circ} \mathrm{C}$ compared with $30^{\circ} \mathrm{C}$. This can be related to lower moisture loss in fillets

smoked at higher temperatures due to case hardening, which prevents effective drying. If this

is so, we would have expected higher shear force with higher smoking temperature, whereas $15^{\circ} \mathrm{C}$.

The higher astaxanthin content at $\mathrm{T} 15^{\circ} \mathrm{C}$ could reflect less breakdown and oxidation of astaxanthin at lower temperature, thus preserving colour. However, Birkeland and co-authors (2004b) found higher astaxanthin retention at higher temperature, 30 vs $20^{\circ} \mathrm{C}$, suggesting higher temperatures cause firmer binding of astaxanthin to the protein binding sites, thereby reducing its degradation.

The higher phenol content in the $\mathrm{T} 15^{\circ} \mathrm{C}$ group is counter to reports of phenol content increasing with smoking temperature, from 20 to $30^{\circ} \mathrm{C}$ for salmon (Cardinal et al., 2001), and from 16 to $32^{\circ} \mathrm{C}$ for herring, Clupea harengus (Sérot et al., 2004). The differences in phenol content between smoking temperatures in our experiments could also be affected by duration of exposure rather than the difference in temperature. This is supported by Sérot et al. (2004), who reported increased phenol content with longer duration, from 60 to 240 minutes in the smokehouse. Phenolic compounds are of considerable importance for the preservation and organoleptic properties of smoked products and increased phenol content will increase shelf 


\subsection{Effect of storage}

The acceptable shelf life of commercial smoked salmon depends on the country of export, varying from 21 to 60 days (Cardinal et al., 2004). Acceptable shelf life is normally connected to sensory deterioration (Truelstrup Hansen and Huss, 1998, Leroi et al., 2001). But also other quality issues, such as stability of colour, texture, fillet gaping and liquid loss can change during storage and are important to the consumer. Our data showed that shear force, gaping and chemical content was stable up to 6 weeks, which covers the shelf life set in many European markets. Our results are in agreement with others, finding minor changes in salmon texture during cold storage (Schubring, 2006, Martinez et al., 2012). Liquid loss is a problem in vacuum packed smoked salmon, and, in agreement with earlier studies, we found liquid loss increased with storage time (Rørå et al., 2003, Løje et al., 2007). Liquid loss is also reported to increase with higher fat content (Mørkøre et al., 2001, Birkeland et al., 2004a), but our results did not support this. It has been reported that colour of vacuum packed salmon is stable during cold storage (Bugueño et al., 2003), but our results show an increase in both redness and lightness during storage.

\section{Conclusion}

The combined analysis of effects of different filleting and processing methods showed that salting method has a greater impact on physio-chemical quality than filleting time, salt target or smoking temperature. Pre-rigor filleting reduces gaping in DS fillets, whereas in IS this effect was not visible. Filleting time had no effect on the absorption of phenol and salt in the fillet. IS increases yield, but leads to lower shear force, paler colour and more gaping. DS lowers yield, but gives higher shear force, more colour and less gaping. Smoking at $15^{\circ} \mathrm{C}$ results in lower yield and L-value, but higher shear force, phenol and astaxanthin compared with $\mathrm{T} 25^{\circ} \mathrm{C}$. The higher phenol content, possible due to longer exposure time at $\mathrm{T} 15^{\circ} \mathrm{C}$, can 
increase shelf life. The combination of DS-T $15^{\circ} \mathrm{C}$ maintained higher astaxanthin content than

IS-T2 $5^{\circ} \mathrm{C}$. Liquid loss and L-value increases during cold storage up to 6 weeks, whereas only

small changes are seen in other quality parameters.

Summing up, our results show injection salting is preferred if yield is the only economic

issue for the producer. However, as texture, gaping and pale colour are responsible for consumer complaints about smoked salmon, the combination of pre-rigor filleting, dry salting and smoking at $15^{\circ} \mathrm{C}$ should be considered a viable option.

\section{References}

\section{Acknowledgement}

This research was performed with the financial support of the European Union in the context of QLK1-2000-01575 project (Improved quality of smoked salmon for the European consumer). The authors would like to thank the staff at IFREMER, IceTEc and IMR for providing the facilities and help necessary to implement the study. Our acknowledgment to Dr. Leslie Robert Noble for his valuable review of the English language.

ARASON, S., NGUYEN, M. V., THORARINSDOTTIR, K. A. \& THORKELSSON, G. 2014. Preservation of fish by curing. In: Boziaris, I. S. (ed.) Seafood Processing; Technology, Quality and Safety. Oxford, UK: John Wiley \& Sons, Ltd.

BARAT, J. M., RODRíGUEZ-BARONA, S., ANDRÉS, A. \& FITO, P. 2003. Cod salting manufacturing analysis. Food Research International, 36, 447-453.

BIRKELAND, S., AKSE, L., JOENSEN, S., TOBIASSEN, T. \& SKÅRA, T. 2007. InjectionSalting of pre rigor Fillets of Atlantic Salmon (Salmo salar). Journal of Food Science, 72, E029-E035.

BIRKELAND, S., BENCZE RØR̊̊, A. M., SKÅRA, T. \& BJERKENG, B. 2004a. Effects of cold smoking procedures and raw material characteristics on product yield and quality parameters of cold smoked Atlantic salmon (Salmo salar L.) fillets. Food Research International, 37, 273-286.

BIRKELAND, S. \& BJERKENG, B. 2005. The quality of cold-smoked Atlantic salmon (Salmo salar) as affected by salting method, time and temperature. International Journal of Food Science \& Technology, 40, 963-976.

BIRKELAND, S., HAARSTAD, I. \& BJERKENG, B. 2004b. Effects of Salt-curing Procedure and Smoking Temperature on Astaxanthin Stability in Smoked Salmon. Journal of Food Science, 69, FEP198-FEP203. 
BIRKELAND, S., SKÅRA, T., BJERKENG, B. \& RØRÅ, A. M. B. 2003. Product Yield and Gaping in Cold-smoked Atlantic Salmon (Salmo salar) Fillets as Influenced by Different Injection-salting Techniques. Journal of Food Science, 68, 1743-1748.

BUGUEÑO, G., ESCRICHE, I., MARTíNEZ-NAVARRETE, N., DEL MAR CAMACHO, M. \& CHIRALT, A. 2003. Influence of storage conditions on some physical and chemical properties of smoked salmon (Salmo salar) processed by vacuum impregnation techniques. Food Chemistry, 81, 85-90.

CARDINAL, M., GUNNLAUGSDOTTIR, H., BJOERNEVIK, M., OUISSE, A., VALLET, J. L. \& LEROI, F. 2004. Sensory characteristics of cold smoked Atlantic salmon (Salmo salar) from European market and relationships with chemical, physical and microbiological measurements. Food Res. Int., 37, 181-193.

CARDINAL, M., KNOCKAERT, C., TORRISSEN, O., SIGURGISLADOTTIR, S., MØRKØRE, T., THOMASSEN, M. \& LUC VALLET, J. 2001. Relation of smoking parameters to the yield, colour and sensory quality of smoked Atlantic salmon (Salmo salar). Food Research International, 34, 537-550.

CHOUBERT, G., BLANC, J.-M. \& COURVALIN, C. 1992. Muscle carotenoid content and colour of farmed rainbow trout fed astaxanthin or canthaxanthin as affected by cooking and smoke-curing procedures. International Journal of Food Science \& Technology, 27, 277-284.

ESPE, M., NORTVEDT, R., LIE, Ø. \& HAFSTEINSSON, H. 2001. Atlantic salmon (Salmo salar L) as raw material for the smoking industry. I: Effect of different salting methods on the oxidation of lipids. Food Chemistry, 75, 411-416.

HULTMANN, L., BENCZE RØRA,, A. M., STEINSLAND, I., SKÅRA, T. \& RUSTAD, T. 2004. Proteolytic activity and properties of proteins in smoked salmon (Salmo salar) effects of smoking temperature. Food Chemistry, 85, 377-387.

HWANG, C.-A. 2009. The probability of growth of Listeria monocytogenes in cooked salmon and tryptic soy broth as affected by salt, smoke compound, and storage temperature. Food Microbiology, 26, 253-258.

JITTINANDANA, S., KENNEY, P. B., SLIDER, S. D. \& KISER, R. A. 2002. Effect of Brine Concentration and Brining Time on Quality of Smoked Rainbow Trout Fillets. Journal of Food Science, 67, 2095-2099.

KJ ÄLLSTRAND, J. \& PETERSSON, G. 2001. Phenolic antioxidants in wood smoke. Science of The Total Environment, 277, 69-75.

LEROI, F., JOFFRAUD, J. J., CHEVALIER, F. \& CARDINAL, M. 2001. Research of quality indices for cold-smoked salmon using a stepwise multiple regression of microbiological counts and physico-chemical parameters. Journal of Applied Microbiology, 90, 578-587.

LØJE, H., JENSEN, K. N., HYLDIG, G., NIELSEN, H. H. \& NIELSEN, J. 2007. Changes in liquid-holding capacity, water distribution and microstructure during chill storage of smoked salmon. Journal of the Science of Food and Agriculture, 87, 2684-2691.

MARTINEZ, O., SALMERÓN, J., GUILLÉN, M. D., PIN, C. \& CASAS, C. 2012. Physicochemical, sensorial and textural characteristics of liquid-smoked salmon (Salmo salar) as affected by salting treatment and sugar addition. International Journal of Food Science \& Technology, 47, 1086-1096.

MØRKØRE, T., HANSEN, A. A., UNANDER, E. \& EINEN, O. 2002. Composition, Liquid Leakage, and Mechanical Properties of Farmed Rainbow Trout: Variation Between Fillet Sections and the Impact of Ice and Frozen Storage. Journal of Food Science, 67, 1933-1938.

MØRKØRE, T., VALLET, J. L., CARDINAL, M., GOMEZ-GUILLEN, M. C., MONTERO, P., TORRISSEN, O. J., NORTVEDT, R., SIGURGISLADOTTIR, S. \& 
THOMASSEN, M. S. 2001. Fat content and fillet shape of Atlantic salmon: Relevance for processing and quality of raw and smoked products. Food engineering and physical properties, 66, 1348-1354.

NIEDZIELA, J. C., MACRAE, M., OGDEN, I. D. \& NESVADBA, P. 1998. Control ofListeria monocytogenesin Salmon; Antimicrobial Effect of Salting, Smoking and Specific Smoke Compounds. LWT - Food Science and Technology, 31, 155-161.

OFSTAD, R., KIDMAN, S., MYKLEBUST, R., OLSEN, R. L. \& HERMANSSON, A.-M. 1995. Liquid-holding Capacity and Structural Changes in Comminuted Salmon (Salmo salar) Muscle as Influenced by $\mathrm{pH}$, Salt and Temperature. Lebensm.-Wiss. $u$.Technol., 28, 329-339.

PETERSON, M. E., PELROY, G. A., PARANJPYE, R. N., POYSKY, F. T., ALMOND, J. S. \& EKLUND, M. W. 1993. Parameters for control of Listeria monocytogenes in smoked fishery products: Sodium chloride and packaging method. Journal of Food Protection, 56, 938-943.

RIZO, A., FUENTES, A., FERNÁNDEZ-SEGOVIA, I., MASOT, R., ALCAÑIZ, M. \& BARAT, J. M. 2013. Development of a new salmon salting-smoking method and process monitoring by impedance spectroscopy. LWT - Food Science and Technology, 51, 218-224.

RØRÅ, A. M. B., FURUHAUG, R., FJÆRA, S. O. \& SKJERVOLD, P. O. 2004. Salt diffusion in pre-rigor filleted Atlantic salmon. Aquaculture, 232, 255-263.

RØRÅ, A. M. B., REGOST, C. \& LAMPE, J. 2003. Liquid holding capacity, texture and fatty acid profile of smoked fillets of Atlantic salmon fed diets containing fish oil or soybean oil. Food Research International, 36, 231-239.

SCHUBRING, R. 2006. Thermal stability, texture, liquid holding capacity and colour of smoked salmon on retail level. Thermochimica Acta, 445, 168-178.

SÉROT, T., BARON, R., KNOCKAERT, C. \& VALLET, J. L. 2004. Effect of smoking processes on the contents of 10 major phenolic compounds in smoked fillets of herring (Cuplea harengus). Food Chemistry, 85, 111-120.

SIGURGISLADOTTIR, S., SIGURDARDOTTIR, M. S., INGVARSDOTTIR, H., TORRISSEN, O. \& HAFSTEINSSON, H. 2001. Microstructure and texture of fresh and smoked Atlantic salmon, Salmo salar L., fillets from fish reared and slaughtered under different conditions. Aquaculture Research, 32, 1-10.

SIGURGISLADOTTIR, S., SIGURDARDOTTIR, M. S., TORRISSEN, O., VALLET, J. L. \& HAFSTEINSSON, H. 2000. Effects of different salting and smoking processes on the microstructure, the texture and yield of Atlantic salmon (Salmo salar) fillets. Food Research International, 33, 847-855.

SKJERVOLD, P. O., FJAERA, S. O., OESTBY, P. B., ISAKSSON, T., EINEN, O. \& TAYLOR, R. 2001a. Properties of salmon flesh from different locations on pre. and post-rigor fillets. Aquaculture, 201, 91-106.

SKJERVOLD, P. O., RORA, A. M. B., FJAERA, S. O., VEGUSDAL, A., VORRE, A. \& EINEN, O. 2001b. Effects of pre-, in-, or post-rigor filleting in live chilled Atlantic salmon. Aquaculture, 194, 315-326.

STATISTICS_NORWAY. 2017. Aquaculture [Online]. Statistics Norway. Available: https://www.ssb.no/jord-skog-jakt-og-fiskeri/statistikker/fiskeoppdrett [Accessed].

TAYLOR, R. G., FJAERA, S. O. \& SKJERVOLD, P. O. 2002. Salmon Fillet Texture is Determined by Myofiber-Myofiber and Myofiber-Myocommata Attachment. Journal of food science, 67, 2067-71.

TRUELSTRUP HANSEN, L. \& HUSS, H. H. 1998. Comparison of the microflora isolated from spoiled cold-smoked salmon from three smokehouses. Food Research International, 31, 703-711. 
TRUELSTRUP HANSEN, L. T., GILL, T. \& HUSS, H. H. 1995. Effects of salt and storagetemperature on chemical, microbiological and sensory changes in cold-smoked salmon. Food Research International, 28, 123-130.

VARLET, V., SEROT, T., KNOCKAERT, C., CORNET, J., CARDINAL, M., MONTEAU, F., LE BIZEC, B. \& PROST, C. 2007. Organoleptic characterization and PAH content of salmon (Salmo salar) fillets smoked according to four industrial smoking techniques. Journal of the Science of Food and Agriculture, 87, 847-854.

WANG, D., TANG, J., CORREIA, L. R. \& GILL, T. A. 1998. Postmortem changes of cultivated Atlantic salmon and their effects on salt uptake. Journal of Food Science, 63, 634-637. 
Table 1. Results from analyses of variance of the data in Fig. 1, 2 and 3, where $\mathrm{P}_{\mathrm{F}}, \mathrm{P}_{\mathrm{M}}, \mathrm{P}_{\mathrm{S}}, \mathrm{P}_{\mathrm{T}}$ are the significance level for the effects of filleting time, salting method, salting target and smoking temperature, and the interaction between selected effects respectively. Gutted body weight and storage time is used as covariate in the model for all parameters, except for gaping, microstructure and phenol where only gutted body weight is used.

\begin{tabular}{|c|c|c|c|c|c|c|c|c|c|}
\hline & \multirow[b]{2}{*}{$\mathrm{P}_{\mathrm{F}}$} & \multirow[b]{2}{*}{$\mathrm{P}_{\mathrm{M}}$} & \multirow[b]{2}{*}{$\mathrm{P}_{\mathrm{S}}$} & \multirow[b]{2}{*}{$\mathrm{P}_{\mathrm{T}}$} & \multirow[b]{2}{*}{$\mathrm{P}_{\text {store as covariate }}$} & \multicolumn{4}{|c|}{ Interactions } \\
\hline & & & & & & $\mathrm{P}_{\mathrm{FxM}}$ & $\mathrm{P}_{\mathrm{M} \times \mathrm{S}}$ & $\mathrm{P}_{\mathrm{FxS}}$ & $\mathrm{Ps}_{\mathrm{x} T}$ \\
\hline Gaping & $<0.001$ & $<0.001$ & $\mathrm{~ns}$ & $\mathrm{~ns}$ & - & $<0.05$ & ns & $\mathrm{ns}$ & ns \\
\hline Microstructure & $<0.05$ & - & - & - & - & & - & - & - \\
\hline Phenol & $\mathrm{ns}$ & $\mathrm{ns}$ & $<0.002$ & $<0.001$ & - & & & & \\
\hline Shear force & $<0.01$ & $<0.001$ & $\mathrm{~ns}$ & $<0.001$ & $\mathrm{~ns}$ & ns & $<0.05$ & $\mathrm{~ns}$ & $\mathrm{~ns}$ \\
\hline Liquid loss & ns & $<0.001$ & ns & $\mathrm{ns}$ & $<0.001$ & ns & ns & $\mathrm{ns}$ & $\mathrm{ns}$ \\
\hline L-value & $\mathrm{ns}$ & $<0.001$ & $<0.001$ & $<0.001$ & $<0.001$ & ns & $\mathrm{ns}$ & $\mathrm{ns}$ & $\mathrm{ns}$ \\
\hline$a^{*}$-value & ns & $<0.001$ & $\mathrm{~ns}$ & $\mathrm{~ns}$ & $<0.001$ & ns & $\mathrm{ns}$ & $\mathrm{ns}$ & $\mathrm{ns}$ \\
\hline Astaxanthin & ns & $<0.005$ & ns & $<0.001$ & ns & ns & $\mathrm{ns}$ & $\mathrm{ns}$ & ns \\
\hline Fat content & $\mathrm{ns}$ & $<0.001$ & ns & $\mathrm{ns}$ & $\mathrm{ns}$ & $\mathrm{ns}$ & $\mathrm{ns}$ & ns & $\mathrm{ns}$ \\
\hline Water content & $\mathrm{ns}$ & $<0.001$ & $<0.001$ & $\mathrm{~ns}$ & $\mathrm{~ns}$ & ns & ns & $\mathrm{ns}$ & ns \\
\hline
\end{tabular}


Table 2. Chemical content of astaxanthin, salt, fat and water in Atlantic salmon fillet, 1 and 4 weeks after processing. DS=dry salting, IS= injection salting, S2.5 and S4.0 refers to $2.5 \%$ and $4.0 \%$ salt target in the muscle, T15 and T25 refers to smoking temperature 15 or $25{ }^{\circ} \mathrm{C}$. Different small letters indicate differences between groups at the same week, analysed with one-way ANOVA.

\begin{tabular}{lcllll}
\hline & Week & DS-T15 & DS-T25 & IS-T15 & IS-T25 \\
\hline Astaxanthin & 1 & $4.6 \pm 0.8^{\mathrm{ac}}$ & $3.9 \pm 1.0^{\mathrm{c}}$ & $4.2 \pm 0.7^{\mathrm{bc}}$ & $3.0 \pm 0.7^{\mathrm{d}}$ \\
$\mathrm{mg} \mathrm{kg}^{-1}$ & 4 & $4.2 \pm 0.8^{\mathrm{a}}$ & $3.5 \pm 0.7^{\mathrm{b}}$ & $3.8 \pm 0.7^{\mathrm{a}}$ & $3.4 \pm 0.6^{\mathrm{a}}$ \\
& & & & \\
\hline Salt g/100g & 1 & $1.8 \pm 0.2$ & $2.4 \pm 0.3$ & $2.4 \pm 0.2$ & $4.0 \pm 0.4$ \\
Fat g/100g & 1 & $12.4 \pm 1.7^{\mathrm{a}}$ & $12.1 \pm 2.1^{\mathrm{a}}$ & $10.3 \pm 2.3^{\mathrm{b}}$ & $10.4 \pm 1.8^{\mathrm{b}}$ \\
& 4 & $10.6 \pm 1.3^{\mathrm{a}}$ & $11.5 \pm 1.6^{\mathrm{a}}$ & $10.5 \pm 1.5^{\mathrm{a}}$ & $11.2 \pm 1.7^{\mathrm{a}}$ \\
& & & & & \\
Water g/100g & 1 & $62.9 \pm 1.0^{\mathrm{a}}$ & $62.1 \pm 1.1^{\mathrm{a}}$ & $68.2 \pm 1.6^{\mathrm{b}}$ & $66.6 \pm 1.5^{\mathrm{b}}$ \\
& 4 & $63.3 \pm 1.2^{\mathrm{a}}$ & $62.0 \pm 0.8^{\mathrm{a}}$ & $67.5 \pm 1.5^{\mathrm{b}}$ & $65.0 \pm 1.6^{\mathrm{b}}$ \\
\hline
\end{tabular}


Figure 1. Flow chart for processing of post rigor filleted Atlantic salmon. Similar procedure was performed for 128 pre-rigor filleted Atlantic salmon.

Figure 2. Fillet yield in Atlantic salmon introduced to different processing procedures; pre=pre rigor filleting and post=post-rigor filleting, DS=dry salting and IS=injection salting; $\mathrm{S} 2.5=2.5 \%$ salt target and $\mathrm{S} 4.0=4.0 \%$ salt target, $\mathrm{T} 15=$ smoked at $15^{\circ} \mathrm{C}$ and $\mathrm{T} 25=$ smoked at $25^{\circ} \mathrm{C}$.

Figure 3. A) Gaping score, B) white muscle fibre cross sectional area and C) phenol content in fillets of Atlantic salmon introduced to different processing procedures; pre=pre rigor filleting and post=post-rigor filleting, $\mathrm{DS}=$ dry salting and $\mathrm{IS}=$ injection salting; $\mathrm{S} 2.5=2.5 \%$ salt target and $\mathrm{S} 4.0=4.0 \%$ salt target, $\mathrm{T} 15=$ smoked at $15^{\circ} \mathrm{C}$ and $\mathrm{T} 25=$ smoked at $25^{\circ} \mathrm{C}$. Different letters indicate significant differences between means.

Figure 4. A) Shear force, B) liquid loss, C) L-value and D) $\mathrm{a}^{*}$-value in fillets of Atlantic salmon introduced to different processing procedures: - - dry salting $15^{\circ} \mathrm{C}$ smoking temperature, $\cdots \circ \cdots$ dry salting $25^{\circ} \mathrm{C}$ smoking temperature, --- $\mathbf{\nabla - - -}$ injection salting $15^{\circ} \mathrm{C}$ smoking temperature, $---\triangle---$ injection salting $25^{\circ} \mathrm{C}$ smoking temperature. 


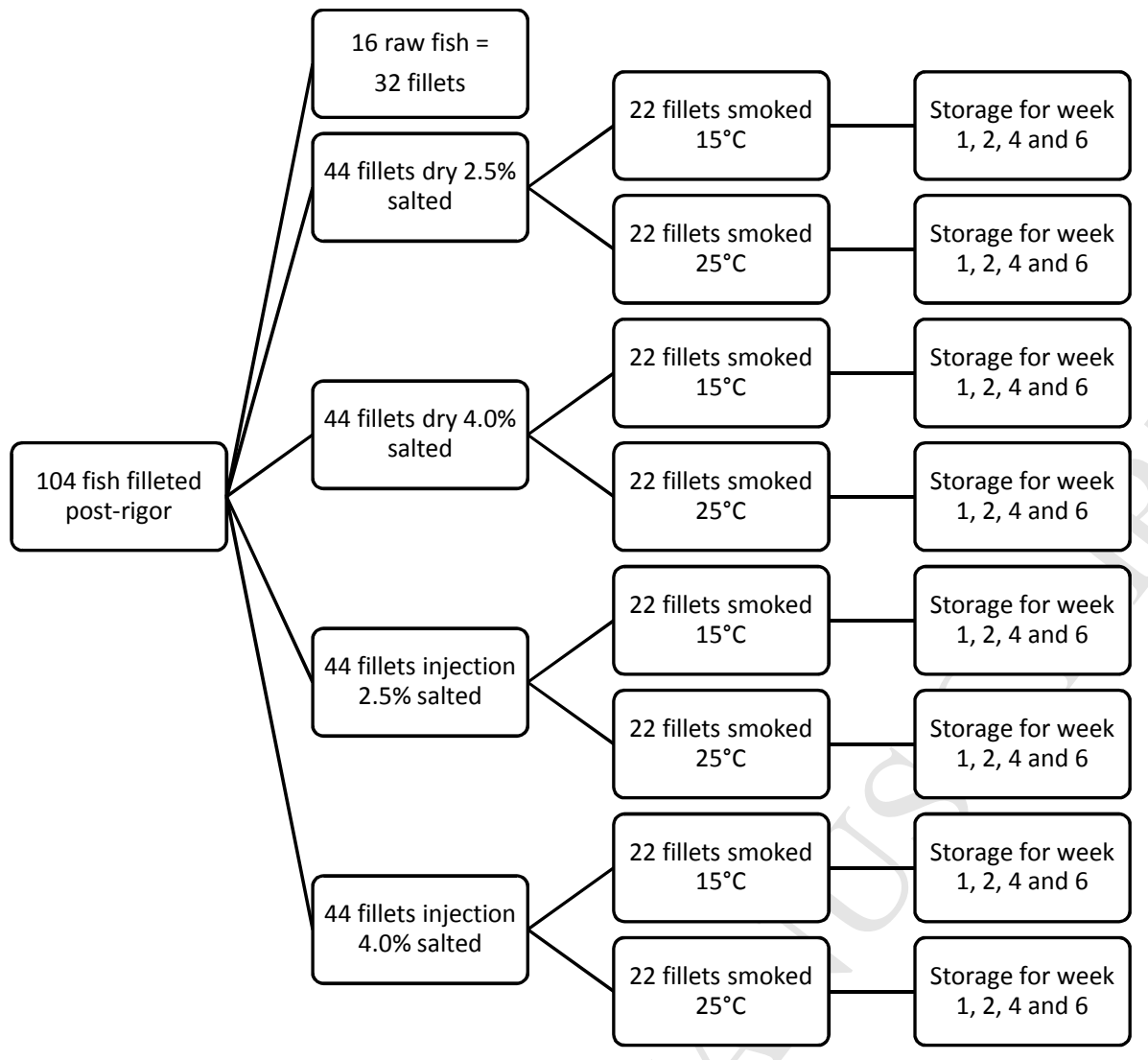


Fillet yield (\%)

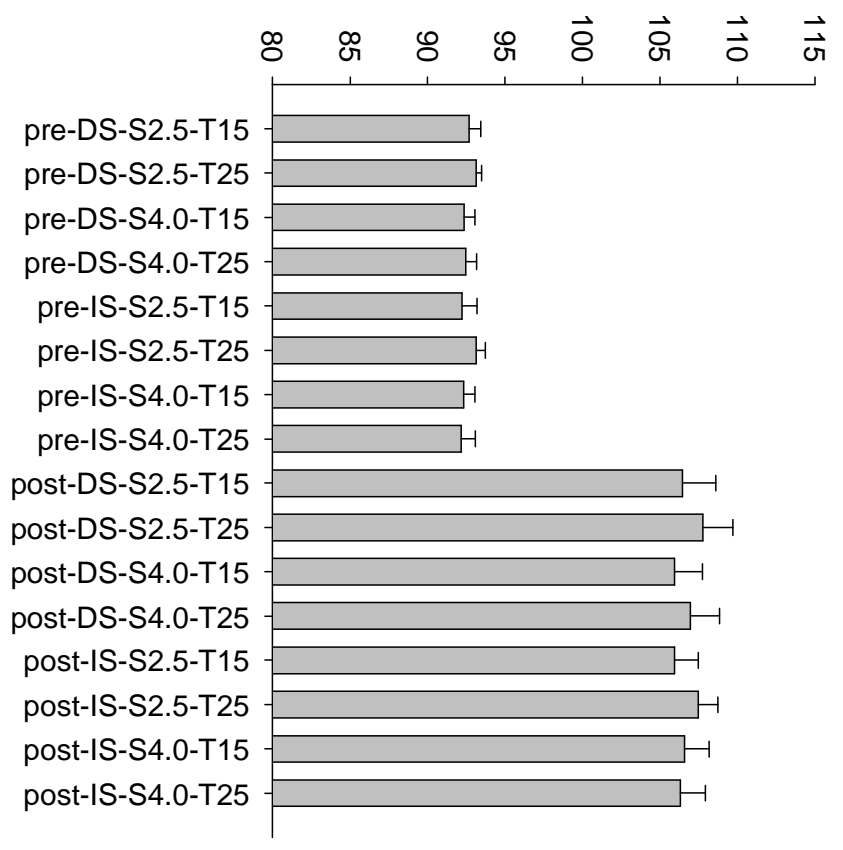



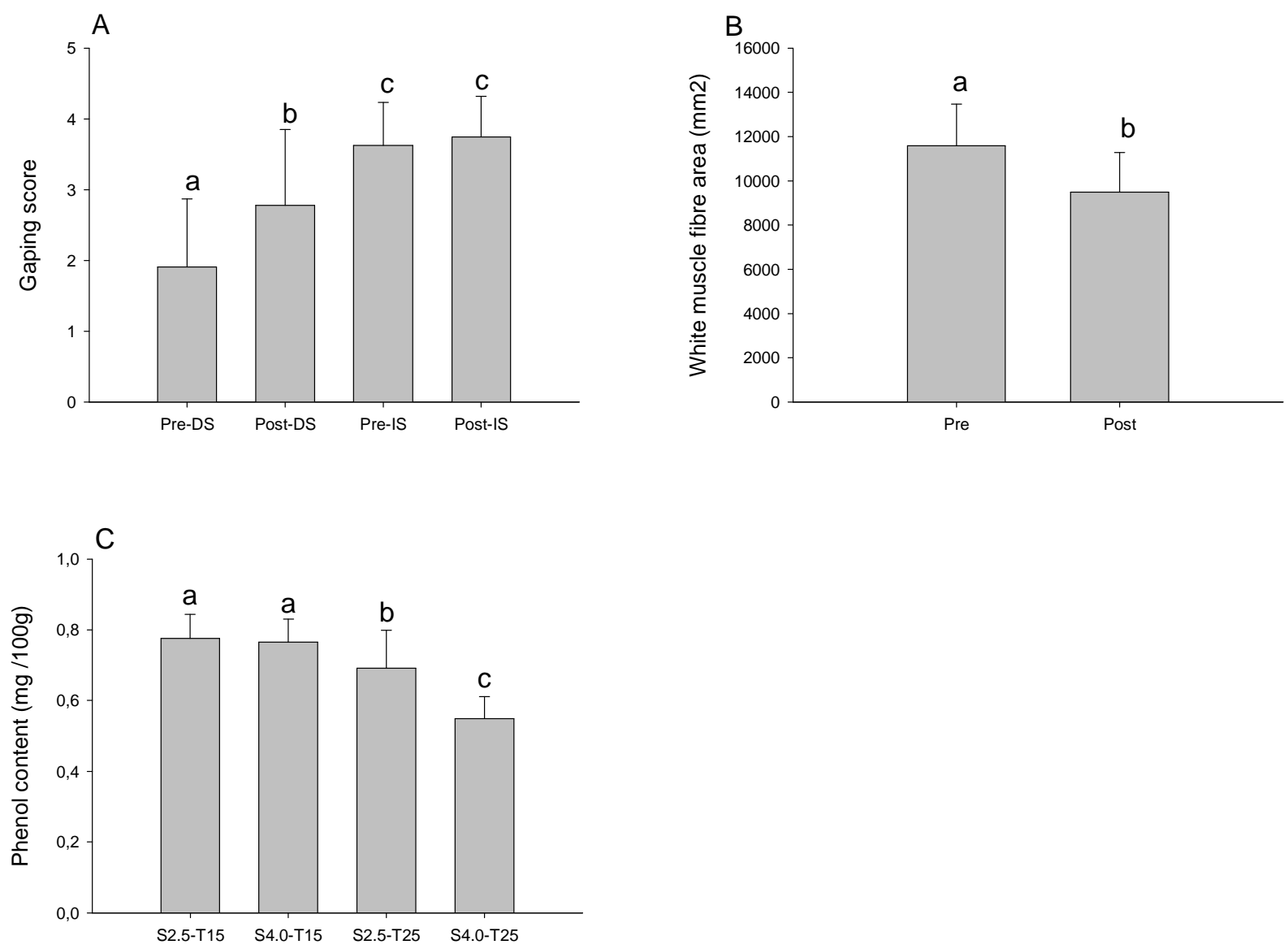

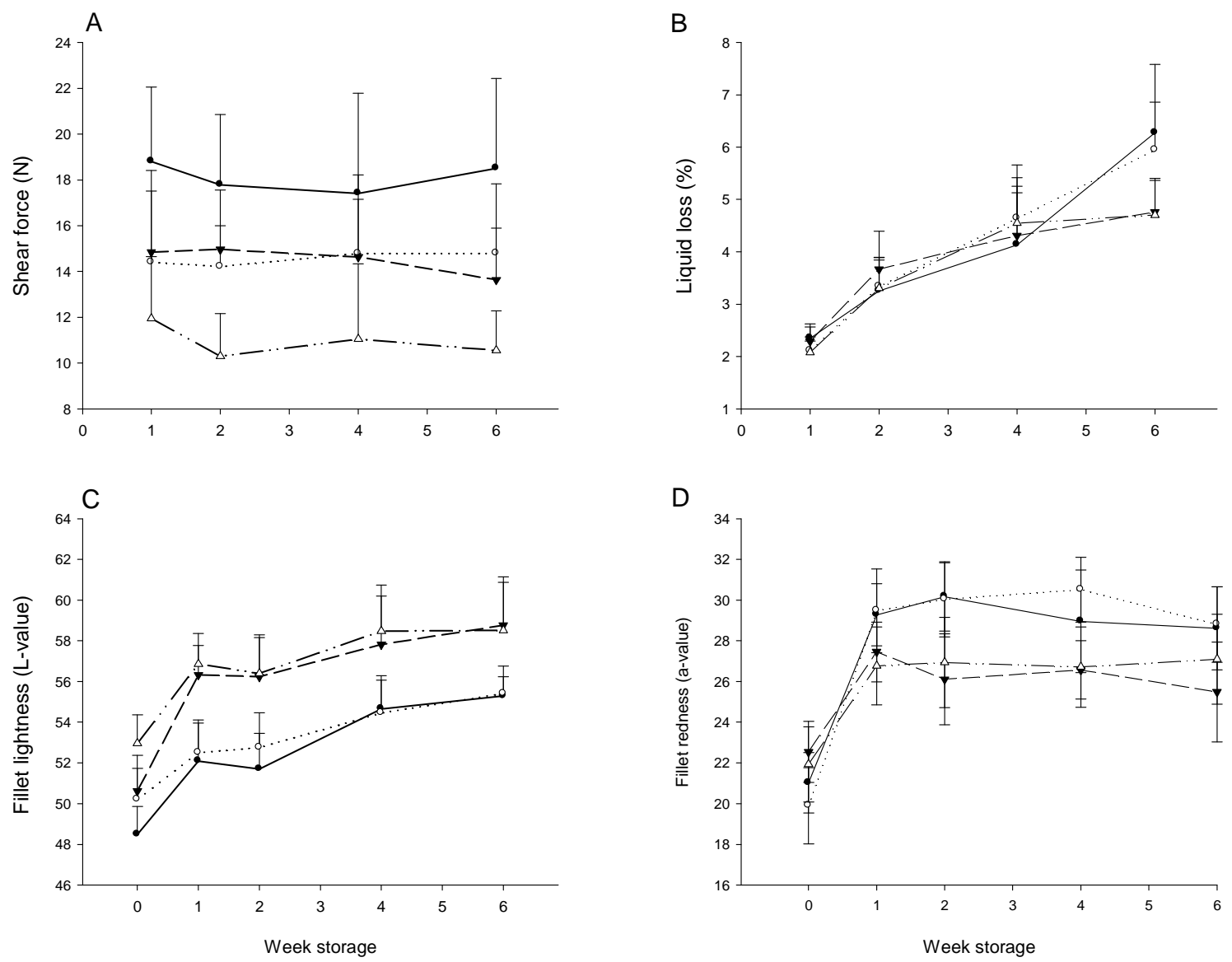